\title{
A PRELIMINARY EVALUATION OF SHALLOW-WATER RHODOLITH BEDS IN BAHIA MAGDALENA, MEXICO
}

\author{
Enrique Ávila ${ }^{1,2, *}$ and Rafael Riosmena-Rodriguez ${ }^{1}$ \\ ${ }^{1}$ Universidad Autónoma de Baja California Sur \\ Programa de Investigación en Botánica Marina, Departamento de Biología Marina \\ (Apartado postal 19-B, La Paz B.C.S. C.P. 23080, México) \\ ${ }^{2}$ Universidad Nacional Autónoma de México \\ Instituto de Ciencias Del Mar y Limnología, Estación El Carmen \\ (Carretera Carmen-Puerto Real km. 9.5, Ciudad del Carmen, Campeche, 24157, México) \\ *Corresponding author: kike@ola.icmyl.unam.mx
}

\begin{abstract}
The aim of the present study was to describe the structure of shallow-water rhodolith beds from Bahia Magdalena, one of the most productive estuarine systems of the Mexican Pacific coasts. From September 2008 to May 2009 four rhodolith beds were found (between 1 and $3 \mathrm{~m}$ depth) and population descriptors such as rhodolith density, size classes, branch density, volume and weight were determined. The dominant rhodolith forming species was Lithophyllum margaritae. The size of beds ranged from 7,600 to $17,800 \mathrm{~m} 2$ approximately with densities from 42.2 to 215.9 ind. $\mathrm{m}^{-2}$. In these beds, L. margaritae shows fruticose and foliose growth forms, from which spherical forms were predominant (81-99\%). Branch density (from 3.0 to 13.3 branches. $\mathrm{cm}^{-2}$ ) varied significantly $(\mathrm{p}<0.05)$ among beds. The average volume (from 2.0 to $400 \mathrm{~mL}$ ) and wet weight (from 32.4 to $84.8 \mathrm{~g}$ ) was not significantly different among sites, but a significant positive correlation $(r=0.95, \mathrm{p}<0.05)$ was found between these parameters. The size of plants ranged from 2.0 to $11.5 \mathrm{~cm}$ with predominant size classes of 40.1-60 mm. Differences in rhodolith density, branch density and sphericity were attributed to possible differences in hydrodynamic conditions among sites. These beds were also a suitable habitat for high diversity of associated sponges. A non-metric multidimensional scaling (MDS) analysis using sponge species data revealed variability in the distribution of sponge assemblages among sites, which is likely the result of differences in environmental conditions. Although these rhodolith beds are not as extensive as those of other regions, our preliminary surveys revealed that they are a common habitat in Bahía Magdalena and likely have an important role in the productivity of this estuarine system.
\end{abstract}

\section{RESUMO}

O objetivo do presente estudo foi descrever a estrutura de bancos de rodolitos de áreas rasas da Bahia Magdalena, um dos sistemas estuarinos mais produtivos da costa pacífica mexicana. Quatro bancos de rodolitos situados entre 1 e $3 \mathrm{~m}$ de profundidade foram avaliados em relação a densidade, classes de tamanho, densidade dos ramos, volume e peso no período de setembro de 2008 a maio de 2009. A espécie dominante no local foi Lithophyllum margaritae. O tamanho dos bancos variou de 7,600 a 17,800 $\mathrm{m}^{2}$ aproximadamente, com densidades de 42.2-215.9 ind. $\mathrm{m}^{-2}$. Foram observadas formas de crescimento fruticosa e folhosa em $L$. margaritae, sendo a forma esférica predominante (81-99\%). A densidade dos ramos $\left(3.0-13.3\right.$ ramos. $\left.\mathrm{cm}^{-2}\right)$ variou significativamente $(\mathrm{p}<0.05)$ entre os bancos. O volume médio $(2.0-400$ $\mathrm{ml})$ e o peso úmido (32.4-84.8 g) não tiveram diferenças significativas entre os locais, mas uma correlação positiva significativa $(\mathrm{r}=0.95, \mathrm{p}<0.05)$ foi encontrada entre os parâmetros. $\mathrm{O}$ tamanho das plantas variou de 2.0 a 11.5 centímetros predominando o padrão entre 40.1-60 mm. As diferenças na densidade de rodolitos, densidade dos ramos e a esfericidade foram atribuídas às condições hidrodinâmicas diferenciadas nos locais. Estes bancos também foram um importante habitat para uma grande diversidade de esponjas associadas. A ordenação das amostras com o escalonamento multidimensional não-métrico (MDS) indicou grande variabilidade na distribuição das assembléias de esponjas entre os bancos, estas diferenças provavelmente são resultado de diferenças nas condições ambientais. Embora estes bancos de rodolitos não sejam tão extensos quanto os de outras regiões, nossas pesquisas preliminares revelaram que estes bancos são um habitat comum na Bahia Magdalena e provavelmente têm um papel importante na produtividade do sistema estuarino da região.

Descritores: Rhodolith beds, Lithophyllum margaritae, distribution, Bahia Magdalena, Baja California, México.

Descritores: Bancos de rodolitos, Lithophyllum margaritae, distribuição, Bahia Magdalena, Baja California, México.

\section{INTRODUCTION}

Rhodolith beds are composed of populations of non-geniculate coralline red macroalgae, which have been recorded forming large biogenic habitats from the low intertidal zone to depths down to $250 \mathrm{~m}$ (BOSENCE, 1983; LITTLER et al., 1991; FOSTER, 2001; KONAR et al., 2006). Currently, several studies 
have highlighted the importance of rhodolith beds in marine ecosystems because: 1) they provide microhabitats and shelter for a high biodiversity of plants and animals (e.g. BIRKETT et al., 1998; HALL-SPENCER, 1998; BARBERA et al., 2003; STELLER et al., 2003; HINOJOSA-ARANGO; RIOSMENA-RODRÍGUEZ 2004; KAMENOS et al., 2004; PEÑA; BÁRBARA, 2008; RIUL et al., 2008), 2) their structures have the potential to provide information on past oceanic conditions (FRANTZ et al., 2000) and 3) they contribute to maintaining the $\mathrm{pH}$ of seawater (CANALS; BALLESTEROS 1997). In addition, they are exploited as a source of calcium carbonate for a wide variety of human uses (e.g., as agricultural and horticultural fertilizer, soil conditioner, toxin eliminator, drinking water purification, biological denitrification and animal fodder additive as well as in the pharmaceutical and cosmetic sectors, in bone surgery and even in the nuclear industry) (LÓPEZ-BENITO, 1963; BLUNDEN et al., 1977; BLUNDEN et al., 1981; GRAY et al., 2000; BARBERA et al., 2003; GRALL, 2003; GRALL; HALL-SPENCER 2003; RIUL et al., 2008).

In the eastern Pacific, rhodolith beds have been recorded in Alaska (USA) (KONAR et al., 2006), in Mexico from the upper Gulf of California to the Revillagigedo Islands (STELLER; FOSTER, 1995; FOSTER et al., 1997; STELLER et al., 2003; HINOJOSA-ARANGO; RIOSMENA-RODRÍGUEZ, 2004) and more recently in the Gulf of Chiriquí, Panama (LITTLER; LITTLER, 2008). Of these, the Gulf of California's rhodolith beds are those which have been most extensively studied as to the location, description and analysis of live and fossil rhodolith communities (e.g. STELLER; FOSTER, 1995; FOSTER et al., 1997; STELLER et al., 2003). Nevertheless, despite the importance of these biogenic habitats in marine environments, little is yet known about the presence of rhodolith beds in most of the Mexican Pacific coastal zone, and even in the eastern Pacific as a whole. Likewise, the organisms associated with these habitats (in this region) are in general poorly known.

The aim of the present study was, therefore, to describe the structure of the shallow rhodolith beds in the Bahía Magdalena, an extremely productive and biologically diverse embayment on the Pacific coast of Baja California Sur, Mexico. Population descriptors such as rhodolith density, average size, sphericity, volume, weight and branch density were quantitatively described and compared with those of other rhodolith beds. Additionally, in this study we hypothesize that rhodolith beds are a suitable habitat for a high diversity of associated organisms, including sponges, one of the least studied groups on rhodolith beds in estuarine systems.

\section{Material And Methods}

Study Area

The study area is located in Bahía Magdalena, a coastal lagoon system located between $24^{\circ} 15^{\prime} \mathrm{N}$ and $25^{\circ} 20^{\prime} \mathrm{N}$ and $111^{\circ} 30^{\prime} \mathrm{W}$ and $112^{\circ} 15^{\prime} \mathrm{W}$ on the Pacific coast of the Baja California peninsula, Mexico (Fig. 1). This anti-estuarine system has an irregular form and is mainly composed of intertidal and shallow areas and relatively narrow mangrove channels with an average depth of $3.5 \mathrm{~m}$ (SCHWEERS et al., 2006). Within this system the sea surface temperatures range from $20.3 \pm 0.5^{\circ} \mathrm{C}$ during January or February to $26.9 \pm 1.0^{\circ} \mathrm{C}$ in September (LLUCH-BELDA et al., 2000). In the shallower zones, salinities reach high levels $(39.2 \%)$ in July and August and low ones $(34.1 \%$ ) in March (ALVAREZBORREGO et al., 1975). The tidal regime (24.8 hours) in Bahía Magdalena is mixed semidiurnal, with periods of higher high water followed by those of lower low water, a condition that produces greater current velocities during ebb tides (LANKFORD, 1977; OBESO-NIEBLAS et al., 1999). Through our field expeditions (from September 2008 to May 2009) in this bay four rhodolith beds were identified, located within the Estero Banderitas (Fig. 1), and in this paper they have been designated as Bed $1\left(24^{\circ} 48^{\prime} 45^{\prime \prime} \mathrm{N}\right.$; $\left.112^{\circ} 05^{\prime} 59^{\prime \prime} \mathrm{W}\right)$, Bed 2 (24⒌'12'’ N; $\left.112^{\circ} 05^{\prime} 24^{\prime}{ }^{\prime} \mathrm{W}\right)$,

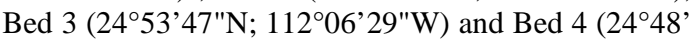
$\left.42^{\prime \prime} \mathrm{N} ; 112^{\circ} 06^{\prime} 32^{\prime \prime} \mathrm{W}\right)$. The distances between the beds ranged from 0.9 to $10 \mathrm{~km}$, approximately. The bottom in the areas adjacent to the rhodolith beds was sandy with small seagrass patches.

\section{Rhodolith Density}

Once the beds were located, the density of the rhodoliths was determined by Scuba diving on three line transects (replicates) of $25 \mathrm{~m}$, placed perpendicularly to the shoreline, within the bed. Five 1 x $1 \mathrm{~m}$ quadrats were placed, $5 \mathrm{~m}$ apart, on each transect. The total number of live rhodoliths within each quadrat was then counted. The total area sampled at each site was of $15 \mathrm{~m}^{2}$ (5 quadrats per transect). Then, a $0.25 \times 0.25 \mathrm{~m}$ quadrat was placed in the upper left-hand corner of each $1 \times 1 \mathrm{~m}$ quadrat and all the live rhodoliths present within it were carefully collected. The rhodoliths were identified in the laboratory in accordance with the eastern Pacific keys (RIOSMENA-RODRIGUEZ et al., 1999; ATHANASIADIS et al., 2004) and the average wet weight $(\mathrm{g})$, size $(\mathrm{cm})$, sphericity, volume $(\mathrm{ml})$ and branch density (branches $\mathrm{cm}^{-2}$ ) were determined. 


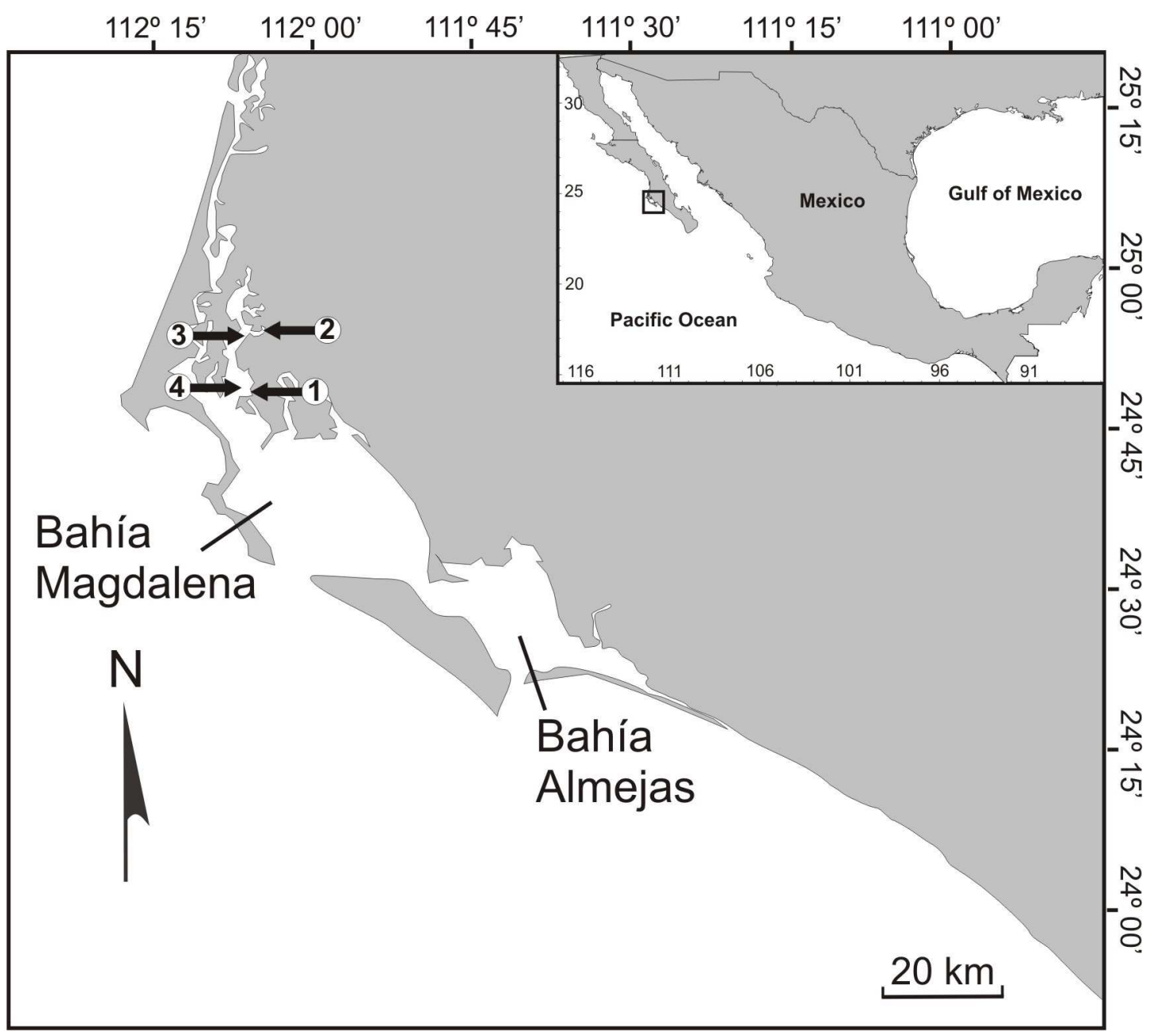

Fig. 1. Study area in the Bahía Magdalena, Baja California Sur, Mexico. The arrows show the study sites (Bed 1, Bed 2, Bed 3 and Bed 4).

\section{Rhodolith Measurements}

A total of 100 rhodolith plants were collected within each bed. Sphericity was calculated from the measurement of the longest (a), shortest (b) and intermediate (c) dimensions (in $\mathrm{cm}$ ) of each plant in accordance with Sneed and Folk's (1958) method and plotted using Tri-plot Ternary diagram plotting software (GRAHAM; MIDGLEY, 2000). This method has been widely used to classify rhodoliths as spheroidal, discoidal or ellipsoidal (BOSCENCE; PEDLEY, 1982; STELLER; FOSTER, 1995; AMADO-FILHO et al., 2007). The average size (cm), i.e., of the greatest dimension of the plants, was measured (STELLER; FOSTER, 1995). With this measurement, size frequency analyses were undertaken for each bed. Branch density was estimated (for each plant) as the average number of apical tips counted in three haphazardly placed $1 \mathrm{~cm}^{2}$ quadrats (STELLER; FOSTER, 1995). The wet weight (g) was also obtained for each specimen using an Ohaus LS5000 portable digital electronic scale. The volume $(\mathrm{mL})$ was determined by displacement in water, using a graduated cylinder (see details in AMADO-FILHO et al., 2007). To determine whether there were significant differences in rhodolith density, size, volume and branch density between sites, one-way analyses of variance (one-way ANOVA) followed by the Student Newman-Keuls test were performed. All data sets (average of each replicate) were previously 
analyzed for normality (Kolmogorov-Smirnov test) and homocedasticity (Cochran's test).

\section{Sponges Associated with Rhodolith Beds}

The sponges associated with each rhodolith bed in January 2009 were also recorded. Their identification was undertaken by the traditional morphological method, which considers external morphology (color, texture and shape) and the arrangement and dimensions of their skeletal elements (see detailed method in BERMAN; BELL, 2010).

The sponge species were recorded on each of the transects used for rhodolith density determinations ( 3 transects per site). To determine whether there was any variability in sponge assemblages within and between beds, analyses of similarity and ordination (non-metric multidimensional scaling, MDS) were performed. The similarity analysis was undertaken in accordance with the ordination techniques recommended by FIELD et al. (1982) and the similarity matrix was based on the presence/absence of sponge species (BRAY; CURTIS, 1957), where 1 indicates a species' presence on the transect and 0 indicates its absence. The MDS was carried out based on the similarity matrix (KRUSKAL; WISH, 1978).

\section{RESUlts}

\section{Species Composition and Growth Form}

The four rhodolith beds surveyed were found at depths of between 1 and $3 \mathrm{~m}$ and their extension ranged from 7,616 $\mathrm{m}^{2}$ (Bed 2) to $17,890 \mathrm{~m}^{2}$ (Bed 1). The dominant rhodolith forming species was Lithophyllum margaritae (Hariot) Heydrich which presents fruticose and foliose growth forms (Fig. 2). The following average values ( \pm standard error) of plant densities, size, volume, weight and sphericity represent this species.

Spherical forms were predominant in Bed 1 (99\%) over both discoidal $(0 \%)$ and ellipsoidal (1\%) forms (Fig. 3). In Bed 2, 80.8\% were spherical, 5\% discoidal and $14.2 \%$ ellipsoidal. In Bed 3, $87.6 \%$ were spherical, $2.1 \%$ discoidal and $10.3 \%$ ellipsoidal. Spherical forms were also predominant in Bed 4 $(81.4 \%)$, while $9.3 \%$ were discoidal and $9.3 \%$ ellipsoidal (Fig. 3).

The branch density varied significantly $(p<$ $0.05)$ between beds. Plants from Bed 1 showed a significantly $(p<0.05)$ higher average density $(11.1 \pm$ 0.21 branches $\left.\mathrm{cm}^{-2}\right)$ than those of Bed $2(9.7 \pm 0.28$ branches $\left.\mathrm{cm}^{-2}\right)$, Bed $3\left(6.9 \pm 0.16\right.$ branches $\left.\mathrm{cm}^{-2}\right)$ and Bed 4 (5.4 \pm 0.16 branches $\mathrm{cm}^{-2}$ ) (Fig. 4).

\section{Rhodolith Density and Dimensions}

The average density ranged from $215.9 \pm$ 3.02 ind $\mathrm{m}^{-2}$ in Bed 1 to $42.2 \pm 5.12$ ind $\mathrm{m}^{-2}$ in Bed 3 . Beds 2 and 4 had intermediate values with $88.2 \pm$ 25.14 ind $\mathrm{m}^{-2}$ and $114.6 \pm 6.07$ ind $\mathrm{m}^{-2}$, respectively (Fig. 4). The rhodolith density showed significant differences between sites (ANOVA, $p<0.01$ ) and it was significantly higher in Bed 1 than at the other three sites (SNK test, $p<0.01$ ).

On the other hand, there were no significant differences (ANOVA, $p>0.05$ ) in average volume between the rhodoliths of Beds 1, 3 and 4 (49.8 \pm 4.99 $\mathrm{mL}, \quad 55.8 \pm 4.80 \mathrm{~mL}$ and $48.8 \pm 5.60 \mathrm{~mL}$, respectively), but it was significantly lower (SNK test, $p>0.01)$ in Bed $2(21.0 \pm 2.09 \mathrm{~mL})$ (Fig. 5). The average weight was, similarly, relatively lower in Bed $2(32.4 \pm 2.84 \mathrm{~g})$ and similar in Beds 1, 3 and 4 (Bed 1 $=79.5 \pm 7.65 \mathrm{~g}$; Bed $3=84.8 \pm 7.07 \mathrm{~g}$; Bed $4=78.7 \pm$ 9.22 g) (Fig. 5). A significant positive correlation (Spearman rank correlation, $\mathrm{r}=0.95, p<0.05$ ) was found between the average weight and volume.

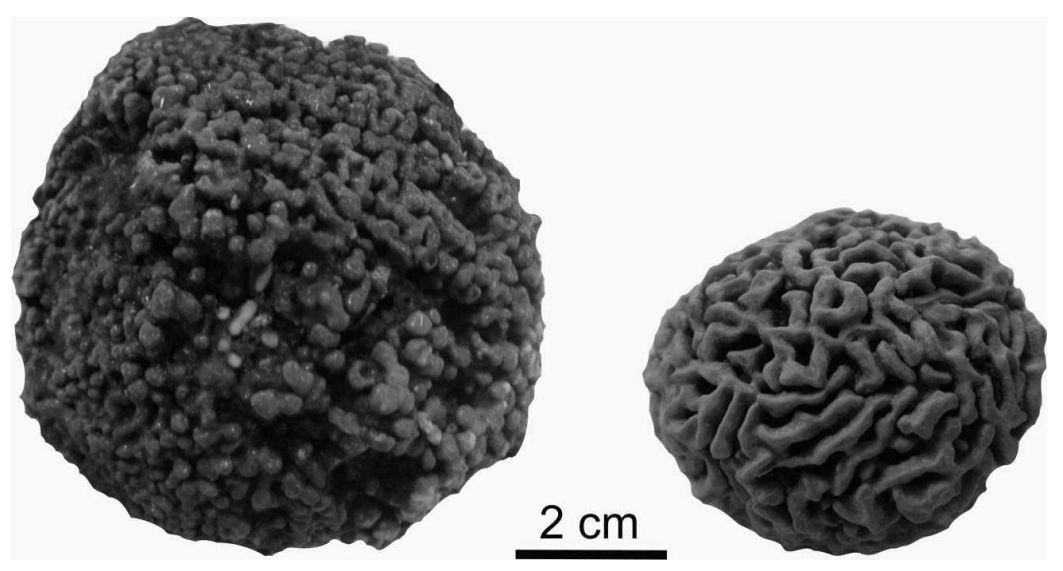

Fig. 2. Specimens of Lithophyllum margaritae from Bahía Magdalena showing fruticose and foliose growth forms. 

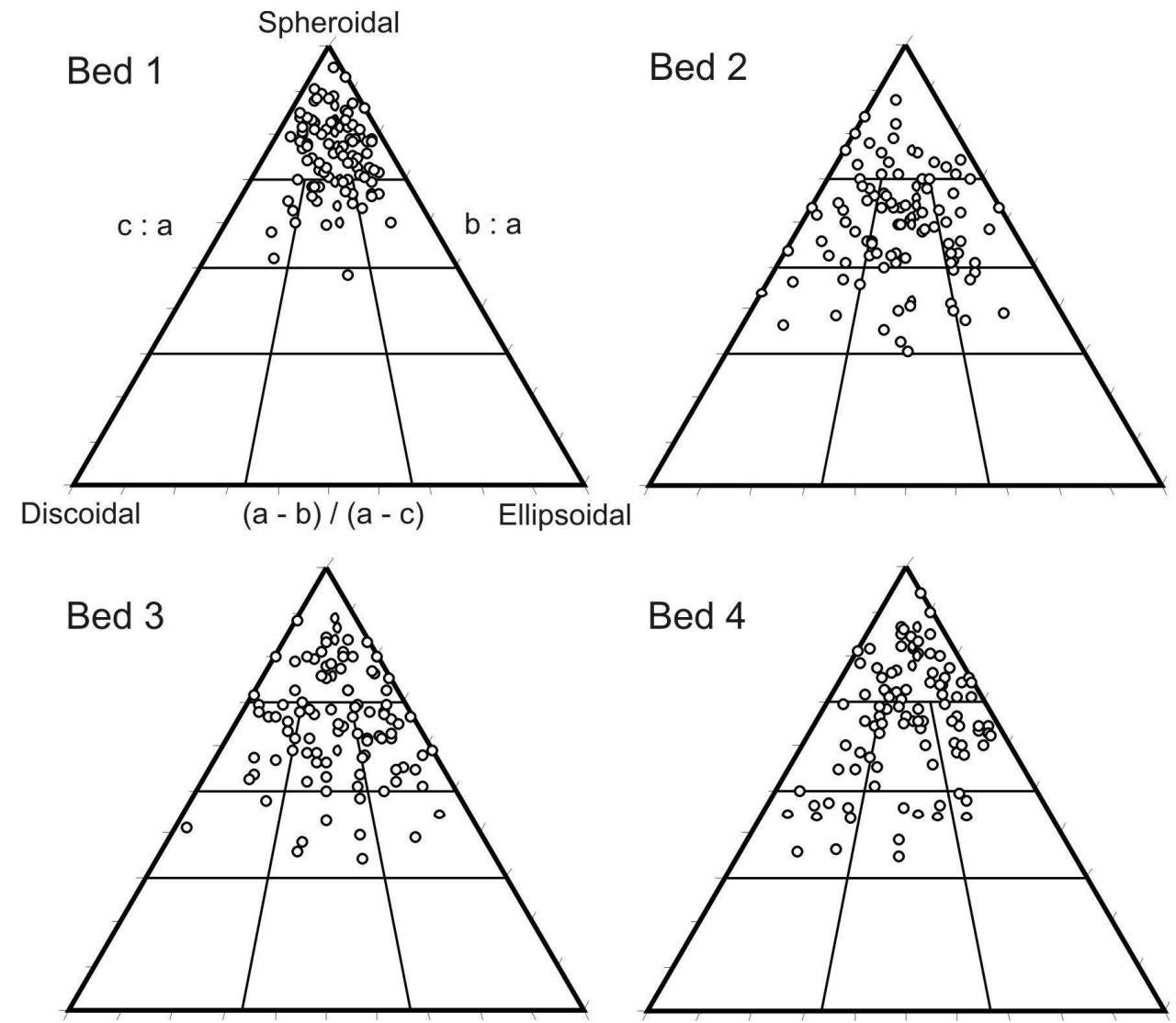

Fig. 3. Sphericity diagrams of rhodoliths from the four sampling sites in Bahía Magdalena. Each point indicates the rhodolith sphericity.

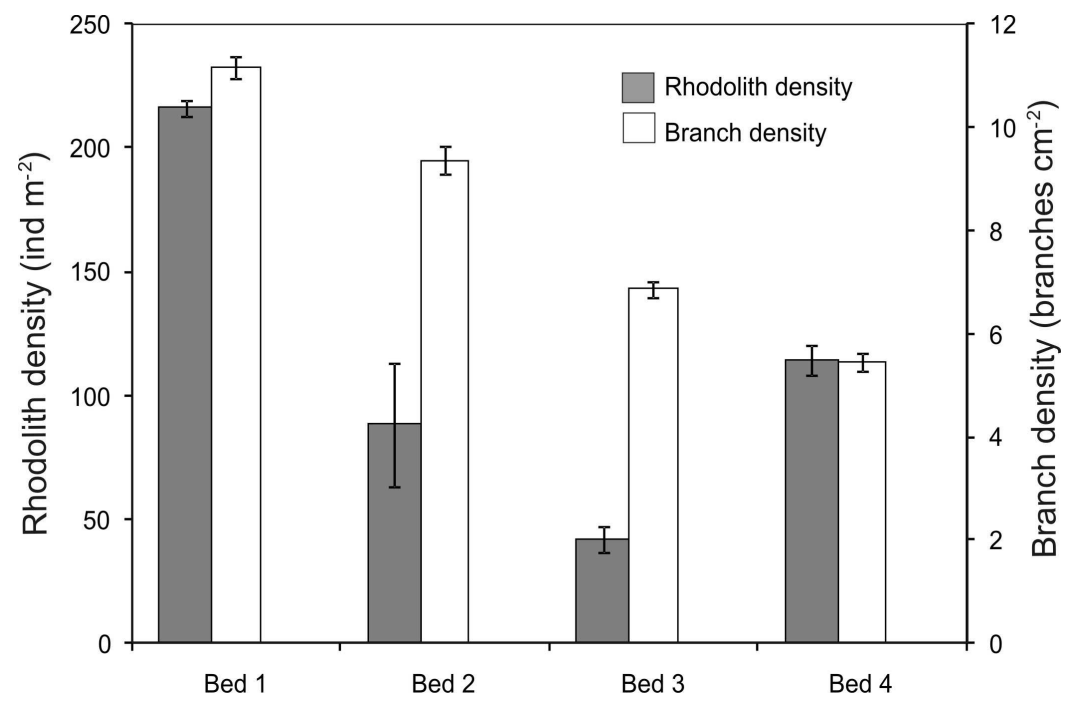

Fig. 4. Variability in the average ( \pm SE) rhodolith density and branch density in the four rhodolith beds. 


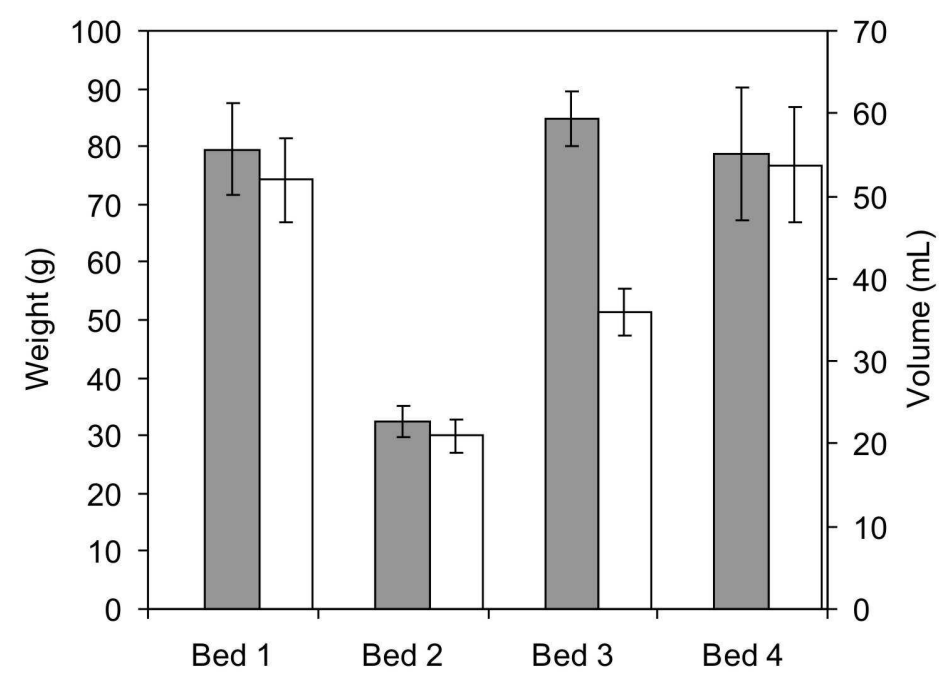

Fig. 5. Average ( \pm SE) wet weight and volume of rhodoliths in the four beds studied.

The size of rhodoliths ranged from 2.0 to $11.5 \mathrm{~cm}$ and there were no significant (ANOVA, $p>$ 0.05) differences in the average sizes between sites (Fig. 6a). The average size was similar in plants of Bed $1(5.58 \pm 0.13 \mathrm{~cm})$ and Bed $4(5.52 \pm 0.14 \mathrm{~cm})$. Likewise, the average size of Bed $2(5.94 \pm 0.18 \mathrm{~cm})$ was similar to that of Bed $3(5.87 \pm 0.18 \mathrm{~cm})$. The
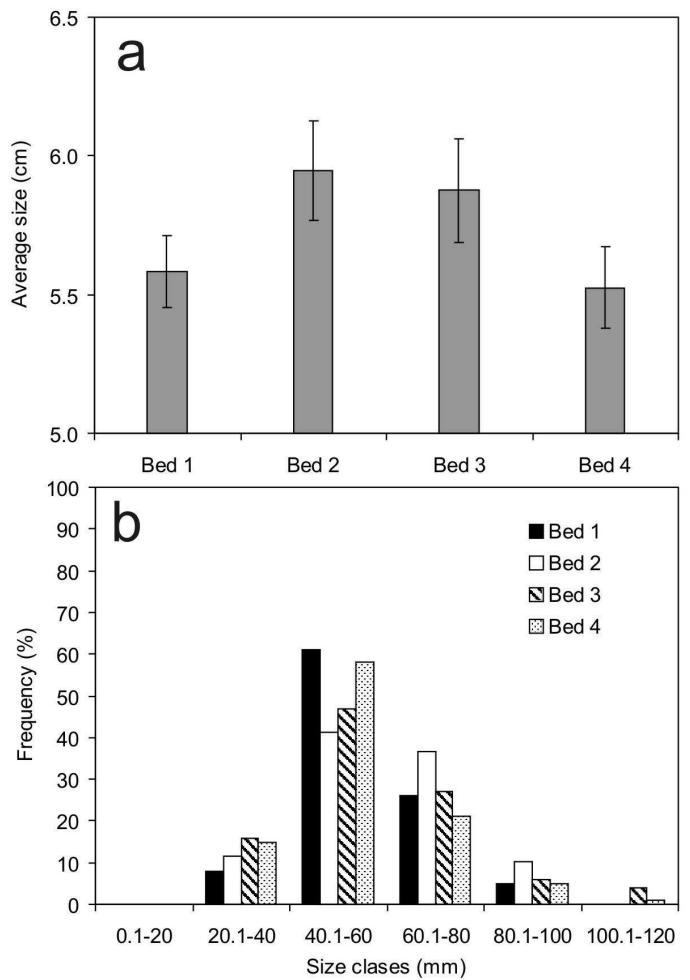

predominant size classes at the four sites ranged from 40.1 to $60 \mathrm{~mm}$ (up to $41 \%$ frequency), followed by specimens of $60.1-80 \mathrm{~mm}$ (between 21 and $37 \%$ frequency) (Fig. 6b). Plants longer than $10 \mathrm{~mm}$ were scarce and were found only in Beds $3(4 \%)$ and 4 $(1 \%)$.

Fig. 6. a) Average ( \pm SE) size and b) size classes (\%) distribution in the four beds studied. 
Associated Sponges

A total of thirteen sponge species were recorded in association with rhodolith beds in the Bahía Magdalena (Table 1). Eleven species were recorded in Bed 1, eight in Bed 2, nine in Bed 3 and twelve in Bed 4. These species presented massive $(69 \%)$, fistulose $(7.6 \%)$, encrusting $(7.6 \%)$ and boring $(15.3 \%)$ growth forms. Only five species were common to all the Beds: Scopalina sp., Halichondria cf. semitubulosa, Haliclona sp., Mycale cf. magnirhapidifera and Cliona euryphylla (Table 1).
The ordination analysis (MDS) of the sponge species indicated that there was some variability in the sponge assemblages both within and between rhodolith beds. The MDS plot separated sponge assemblages into five main groups with $60 \%$ similarity. Group 1 included the three replicates of Beds 1 and 4 ; group 2 two replicates of Bed 2; group 3 two replicates of Bed 3; group 4 one replicate of Bed 2 and group 5 one replicate of Bed 3 (Fig. 7). The stress of 0.1 in the MDS indicates an acceptable representation.

Table 1. Sponge species found in rhodolith beds from Bahía Magdalena (x presence, -absence).

\begin{tabular}{|c|c|c|c|c|}
\hline Sponge species & Bed 1 & Bed 2 & Bed 3 & Bed 4 \\
\hline Scopalina sp. Schmidt, 1862 & $\mathrm{x}$ & $\mathrm{x}$ & $\mathrm{x}$ & $\mathrm{x}$ \\
\hline Halichondria panicea (Pallas, 1766) & $\mathrm{x}$ & $\mathrm{x}$ & $\mathrm{x}$ & $\mathrm{x}$ \\
\hline Halichondria cf. semitubulosa Lieberkühn, 1859 & $\mathrm{x}$ & $\mathrm{x}$ & $\mathrm{x}$ & $\mathrm{x}$ \\
\hline Mycale cf. magnirhaphidifera van Soest, 1984 & $\mathrm{x}$ & $\mathrm{x}$ & $\mathrm{x}$ & $\mathrm{x}$ \\
\hline Mycale cecilia de Laubenfels, 1936 & $\mathrm{x}$ & - & - & $\mathrm{x}$ \\
\hline Suberites aurantiaca (Duchassaing and Michelotti, 1864) & $\mathrm{x}$ & $\mathrm{x}$ & - & $\mathrm{x}$ \\
\hline Dysidea cachui Carballo et al. 2006 & $\mathrm{x}$ & - & $\mathrm{x}$ & $\mathrm{x}$ \\
\hline Cliona euryphylla Topsent, 1888 & $\mathrm{x}$ & $\mathrm{x}$ & $\mathrm{x}$ & $\mathrm{x}$ \\
\hline Cliona californiana de Laubenfels, 1932 & $\mathrm{x}$ & - & $\mathrm{x}$ & $\mathrm{x}$ \\
\hline Haliclona sp. Grant, 1836 & $\mathrm{x}$ & - & $\mathrm{x}$ & $\mathrm{x}$ \\
\hline Haplosclerida sp. 1 Topsent, 1928 & $\mathrm{x}$ & - & - & $\mathrm{x}$ \\
\hline Haplosclerida sp. 2 Topsent, 1928 & - & $\mathrm{x}$ & - & - \\
\hline Clathrinida sp. Hartman, 1958 & - & $\mathrm{x}$ & $\mathrm{x}$ & $\mathrm{x}$ \\
\hline
\end{tabular}

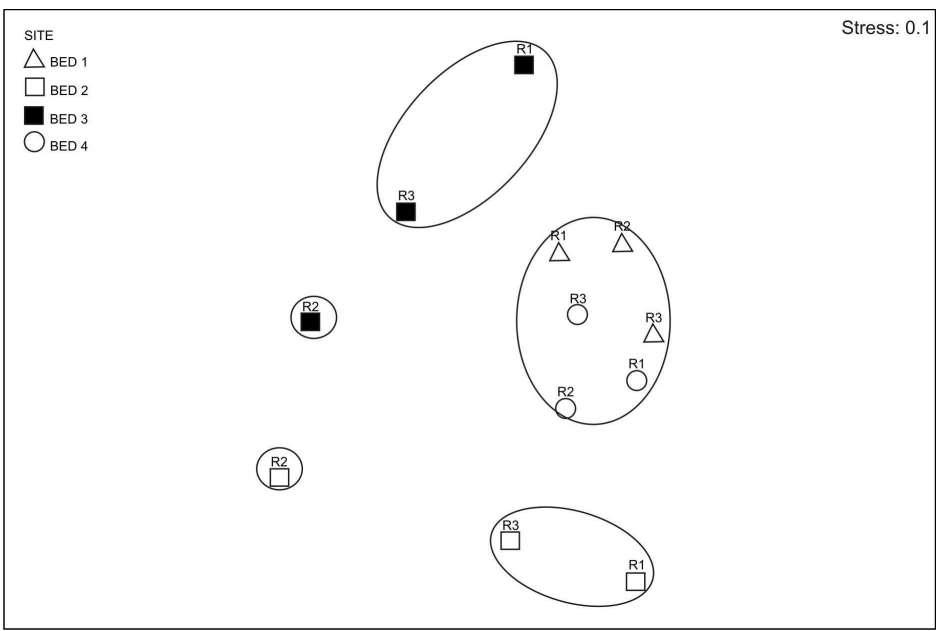

Fig. 7. Non-metric multidimensional scaling (MDS) plot constructed from a BrayCurtis similarity matrix of presence/absence of the sponge species recorded in four rhodolith beds in the Bahía Magdalena. Ellipses around data points indicate similarities (at $60 \%$ similarity) of sponge assemblages determined by cluster analysis. 


\section{Discussion}

This study contributes to our knowledge of the rhodolith beds of the Mexican Pacific as this is the first time they have been recorded on the west coast of the Baja California peninsula. And, according to Foster (2001), this is also one of the few studies describing living rhodolith beds in the eastern Pacific. The dominant rhodolith forming species in Bahía Magdalena was Lithophyllum margaritae, which has also been considered one of the commonest species in the Gulf of California (RIOSMENA-RODRÍGUEZ et al., 1999; STELLER et al., 2003; STELLER et al., 2007). The dimensions (size, branch density and volume) and weight obtained in this study were within the range of specimens of L. margaritae found in the Gulf of California (STELLER; FOSTER, 1995; STELLER et al., 2003). However, in the Bahía Magdalena beds the plants seem to attain greater sizes (ranging from 2.0 to $11.5 \mathrm{~cm}$ in diameter) and volume (from 2.0 to $400 \mathrm{~mL}$ ) than those described for the shallow areas of the Bahía Concepción (average size ranging from 2.1 to $4.8 \mathrm{~cm}$ and volume from 2.1 to $34.9 \mathrm{~mL}$ ) (STELLER et al., 2003). Larger specimens were scarce and generally found at the edges of the beds. Similarly, in this study the rhodolith density (from 42.2 to 215.9 ind $\mathrm{m}^{-2}$ ) and branch density (from 3.0 to 13.3 branches $\mathrm{cm}^{-2}$ ) were lower than the values documented for the same species in the Bahía Concepción (average density [ \pm SE] of $8538 \pm 2528$ ind $\mathrm{m}^{-2}$ and from 4.4 to 21.8 branches $\mathrm{cm}^{-2}$ ) (STELLER et al., 2003).

As has already been documented, apart from light and temperature the main factor affecting distribution stability, shape, density and branching patterns of rhodoliths is the hydrodynamic forces (BOSENCE, 1976; HILY et al., 1992; STELLER; FOSTER, 1995; BASSO, 1998). Although, in this study, hydrodynamic conditions were not measured, the tidal currents appear to be a major hydrodynamic force leading to the accumulation of rhodoliths in certain areas of the bay, as rhodolith beds were always found near or within tidal channels. These tidal currents reach speeds of up to $120 \mathrm{~cm} \mathrm{~s}^{-1}$ at the entrance to the bay (ROBINSON et al., 2007).

On the other hand, the influence of waves produced by tropical storms or hurricanes on the spatial distribution of these rhodolith beds cannot be ignored as these meteorological phenomena frequently make their landfall in this region (MARTÍNEZGUTIÉRREZ; MAYER, 2004). Unlike the Gulf of California's beds, which are generally larger (of the order of kilometers), they occur in two primary watermotion regimes, wave-dominated and currentdominated, and beds have been characterized accordingly as wave beds and current beds (STELLER et al., 2009).
As has been commented above, the factors that might help to explain differences in rhodolith morphology between sites vary. Branch density and size generally decrease with increasing depth and have been related to factors such as water motion and sedimentation (STELLER; FOSTER, 1995). In this study, the higher values of rhodolith density and branch density as well as a high proportion of spherical forms occurred in Bed 1, which possibly reflects an environment with relatively intense water motion, as has been suggested in previous studies (MARRACK, 1999). Although depth did not vary significantly between sites, Bed 1 was located in a relatively more exposed zone (at the entrance of Estero Banderitas) than the other three sites. Nevertheless, it has also been observed that rhodolith morphology may not simply be a function of water motion (STELLER; FOSTER, 1995; FOSTER, 2001) but that rhodolith rotation may be affected by processes other than currents (e.g., disturbance by grazing fish and benthic invertebrates and epiphyte overgrowth) (GLYN, 1974; SCOFFIN et al., 1985; MARRACK, 1999). Thus further studies are required to examine possible environmental differences (hydrodynamic conditions and sedimentation) between sites.

Our surveys conducted in Bahía Magdalena revealed that rhodolith beds are a common macroalgal habitat within this system and together with mangrove roots and shell banks also provide hard substrata for a great diversity of invertebrates and epiphytic seaweeds. In the case of sponges (one of the most diverse groups), the MDS plot indicated that there is variability in sponge assemblages within and between sites (with only $38 \%$ of species shared). This analysis (60\% similarity) included within one and the same group all the replicates of Beds 1 and 4, which may be because the relatively short distance between these sites $(0.9 \mathrm{~km})$ allows the flow of species between them ( $85 \%$ of their species are shared). Moreover, Beds 2 and 3 showed a higher within site variability for sponge species data. That variability suggests that sponge assemblages were not homogeneous between replicates of one and the same rhodolith bed, but varied over small spatial scales. These findings are consistent with those of Bell and Barnes (2003) and Carballo and Nava (2007), who found that sponge assemblages varied considerably between rocky habitats that were less than $50 \mathrm{~m}$ apart. The factors likely to be responsible for this variation include larval supply, recruitment, physical disturbance and biological interactions (UNDERWOOD et al., 1991).

It was also noted that although this is one of the most important embayments of northwestern Mexico, the rhodolith beds seem to be less impacted by human activities (fishery and urban pollution) than those described in other places worldwide (HALLSPENCER; MOORE, 2000; STELLER et al., 2009). 
In brief, this is a preliminary study that describes for the first time the structural characteristics of the rhodolith beds of the Bahía Magdalena and the associated sponge species that inhabit them. The dominant rhodolith forming species (L. margaritae) in this estuarine system showed similar structural dimensions to those of specimens of the same species in the Gulf of California. Likewise, although these beds are relatively smaller than those described in other places around the world, they constitute an available substrate for a great diversity of associated organisms. Undoubtedly, further ecological studies are required to determine the abundance of associated epibionts (flora and fauna) and the role of rhodolith beds in the productivity of this ecosystem as well as potential benefits to local fisheries (e.g., as nursery areas for scallops) as has been demonstrated in relation to other rhodolith beds (HALL-SPENCER, 1998; STELLER; CÁCERES-MARTÍNEZ， 2009). In addition, the implementation of a management and conservation plan for these fragile environments is also necessary.

\section{ACKNOWLEDGEMENTS}

We would like to thank G. Hinojosa-Arango for providing the facilities at The School for Field Studies, San Carlos. We also wish to thank A. Romero, F. Inzunza and C. Romero for their help in carrying out the field work; CONACYT for E. Avila's Postdoctoral Grant; J.M. Vivas and A. SanchezRodríguez for their help in the field samplings and C. Henriques for her help in the translation of the abstract into Portuguese.

\section{REFERENCES}

ALVAREZ-BORREGO, S.; GALINDO-BECT, L. A.; CHEE-BARRAGAN A. Características hidroquímicas de Bahía Magdalena, B.C.S. Cienc. Mar., v. 2, n. 2, p. 94-110, 1975 .

AMADO-FILHO, G. M.; MANEVELDT, G.; MANSO, R. C. C.; MARINS-ROSA, B. V.; PACHECO, M. R.; GUIMARAES, S. M. P. B. Estructura de los mantos de rodolitos de 4 a 55 metros de profundidad en la costa sur del estado de Espíritu Santo, Brasil. Cienc. Mar., v. 33, n. 4, p. 399-410, 2007.

ATHANASIADIS, A.; LEBEDNIK, P. A.; ADEY, W. H. The genus Mesophyllum (Melobesioideae, Corallinales, Rhodophyta) on the Northern Pacific coast of North America. Phycologia, v. 43, p. 126-165, 2004.

BARBERA, C.; BORDEHORE, C.; BORG, J. A.; GLÉMAREC, M.; GRAS, J.; HALL-SPENCER, J. M.; DE LA HUZ, CH.; LANFRANCO, E.; LASTRA, M.;
MOORE, P. G.; MORA, J.; PITA, M. E.; RAMOSESPLÁ, A. A.; RIZZO, M.; SÁNCHEZ-MATA, A.; SEVA, A.; SCHEMBRI, P. J.; VALLE, C. Conservation and management of northeast Atlantic and Mediterranean maërl beds. Aquat. Conserv.: Mar. Freshw. Ecosyst., v. 13, p. 65-76, 2003.

BASSO, D. Deep rhodolith distribution in the Pontian Islands, Italy: a model for the paleoecology of a temperate sea. Palaeogeogr., Palaeoclimatol., Palaeoecol., v. 137, p. 172-187, 1998.

BELL, J. J.; BARNES, D. K. A. Effect of disturbance on assemblages: an example using Porifera. Biol. Bull., v. 205, p. 114-159, 2003.

BERMAN, J.; BELL, J. J. Spatial variability of sponge assemblages on the Wellington south coast, New Zealand. Open Mar. Biol. J. v. 4, p. 12-25, 2010.

BIRKETT, D. A.; MAGGS, C. A.; DRING, M. J. Maërl: An overview of dynamic and sensitivity characteristics for conservation management of marine SACs. v. 6. Scottish Assoc. Marine Science/UK Marine SACs Project, 1998

BLUNDEN, G.; FARNHAM, W. F.; JEPHSON, N.; BARWELL, C. J.; FENN, R. H.; PLUNKETT, B. A. The composition of maerl beds of economic interest in northern Brittany, Cornwall and Ireland. Proc. Int. Seaweed Symp. v. 10, p. 651-656, 1981.

BLUNDEN, G.; FARHAM, W. F.; JEPHSON, N.; FENN, R. H.; PLUNKETT, B. A. The composition of maerl from the Glenan Islands of Southern Brittany. Bot. Mar., v. 20, p. 121-125, 1977.

BOSENCE, D. W. J. Ecological studies on two unattached coralline algae from western Ireland. Paleontology v. 19, p. 365-395, 1976 .

BOSCENCE, D. W. J.; PEDLEY, H. M. Sedimentology and palaeoecology of Miocene coralline algal biostrome from the Maltese Islands. Palaeogeogr. Palaeoclimatol. Palaeoecol., v. 38, p. 9-43, 1982.

BOSENCE, D. W. J. The occurrence and ecology of recent rhodoliths-a review, In: TADEUSZ, M. P. (Ed.). Coated grains. Springer-Verlag, p. 225-242, 1983.

BRAY, J. R.; CURTIS, J. T. An ordination of the upland forest communities of Southern Wisconsin. Ecol. Monogr., v. 27, p. 325-349, 1957.

CANALS, M.; BALLESTEROS, E. Production of carbonate particles by phytobenthic communities on the MallorcaMenorca shelf, northwestern Mediterranean Sea. Deep Sea Res., v. 44, p. 611-629, 1997.

CARBALLO, J. L.; NAVA, H. A comparison of sponge assemblage patterns in two adjacent rocky habitats (tropical Pacific Ocean, Mexico). Ecoscience, v. 14, p. 92-102, 2007.

FIELD, J. G.; CLARKE, K. R.; WARWICK, R. M. A practical strategy for analysing multispecies distribution patterns. Mar. Ecol. Prog. Ser., v. 8, p. 3752, 1982.

FRANTZ, B. R.; KENNETH, M. K.; COALE, H.; FOSTER, M. S. Growth rate and potential climate record from a rhodolith using $14 \mathrm{C}$ accelerator mass Spectrometry. Limnol. Oceanogr., v. 45, n. 8, p. 1773-1777, 2000.

FOSTER, M. S. Rhodoliths: Between rocks and soft places. J. Phycol., v. 37, p. 659-667, 2001.

FOSTER, M. S.; RIOSMENA-RODRIGUEZ, R.; STELLER, D. L.; WOELKERLING, W. J. Living rhodolith beds in the Gulf of California and their implications for 
paleoenvironmental interpretation. Geol. Soc. Am. Spec. Pap., v. 318, p. 127-139, 1997.

GLYN, P. W. Rolling stones among the Scleractinia: mobile coralliths in the Gulf of Panama. Proc. 2nd Int. Coral Reef Symp., v. 2, p. 183-198, 1974.

GRAHAM, D. J.; MIDGLEY, N. G. Graphical representation of particle shape using triangular diagrams: an excel spreadsheet method. Earth Surf. Proc. Land., v. 25, p. 1473-1477, 2000.

GRALL, J. Fiche de synthèse sur les biocénoses: les bancs de maërl. Institut français de recherche pour lexploitation de la mer (IFREMER). p. 1-20, 2003.

GRALL, J.; HALL-SPENCER, J. M. Problems facing maërl conservation in Brittany. Aquat. Conserv. Mar. Freshw. Ecosyst., v. 13, p. 55-64, 2003.

GRAY, S.; KINROSS, J.; READ, P.; MARLAND, A. The nutrient assimilative capacity of maërl as a substrate in constructed wetland systems for waste treatment. Water Res., v. 34, n. 8, p. 2183-2190, 2000.

HALL-SPENCER, J. M. Conservation issues relating to maërl beds as habitats for molluscs. J. Conchiol. Spec. Publ., v. 2, p. 271-286. 1998.

HALL-SPENCER, J. M.; MOORE, P. G. Scallop dredging has profound, long-term impacts on maerl habitats. ICES J. Mar. Sci., v. 57, p. 1407-1415. 2000.

HINOJOSA-ARANGO, G.; RIOSMENA-RODRÍGUEZ, R. Influence of rhodolith-forming species and growth-form on associated fauna of rhodolith beds in the central-west Gulf of California, Mexico. PSZN: Mar. Ecol., v. 25, p. 109-127, 2004.

HILY, C.; POTIN, P.; FLOCH, J. Y. Structure of subtidal algal assemblages on soft-bottom sediments: fauna/flora interactions and role of disturbances in the Bay of Brest, France. Mar. Ecol. Prog. Ser., v. 85, p. 115-130, 1992.

KAMENOS, N. A.; MOORE, P. G.; HALL-SPENCER, J. M. The attachment of the juvenile queen scallop (Aequipecten opercularis) to maërl in mesocosm conditions: juvenile habitat selection. J. Exp. Mar. Biol Ecol., v. 306, p. 139-155, 2004.

KONAR, B.; RIOSMENA-RODRIGUEZ, R.; IKEN, K. Rhodolith bed: a newly discovered habitat in the North Pacific Ocean. Bot. Mar., v. 49, p. 355-359, 2006.

KRUSKAL, J. B.; WISH, M. (Ed). Multidimensional scaling. Beverly Hills, CA: Sage Publications, 1978.

LANKFORD, R. R. Coastal lagoons of Mexico: Their origin and classification. In: WILEY, M. (Ed.). Estuarine Processes. New York: Academic Press, 1977. p. 182215.

LITTLER, M. M.; LITTLER, D. S. Coralline algal rhodoliths form extensive benthic communities in the Gulf of Chiriquí, Pacific Panama. Coral Reefs, v. 27, n. 3, p. 553, 2008

LITTLER, M. M.; LITTLER, D. S.; HANISAK, M. D. Deepwater rhodolith distribution, productivity, and growth history at sites of formation and subsequent degradation. J. Exp. Mar. Biol. Ecol., v. 150, p. 163-182, 1991.

LLUCH-BELDA, D.; HERNANDEZ-RIVAS, M.; SALDIERNA-MARTINEZ, R.; GUERREROCABALLERO, R. Variabilidad de la temperatura superficial del mar en Bahía Magdalena, B.C.S. Oceánides, v. 15, p. 11-23, 2000.

LÓPEZ-BENITO, M. Estudio de la composición química del Lithothamnion calcareum (Aresch.) y su aplicación como corrector de cultivo. Inv. Pesq., v. 23, p. 53-70, 1963.
OBESO-NIEBLAS, M.; GAVINO-RODRIGUEZ， J. H.; JIMENEZ-ILLESCAS, A. R. Modelación de la marea en el sistema lagunar Bahía Magdalena-Almejas, B.C.S., Mexico. Oceánides, v. 14, n. 2, p. 79-88, 1999.

MARRACK, E. C. The relationship between water motion and living rhodolith beds in the southwestern Gulf of California, Mexico. Palaios, v. 14, p. 159-171. 1999.

MARTINEZ-GUTIERREZ, G.; MAYER, L. Huracanes en Baja California, México y sus implicaciones en la sedimentación en el Golfo de California. Geos, v. 24, n. 1, p. 56-64, 2004.

PEÑA, V.; BÁRBARA, I. Biological importance of an Atlantic European maërl bed in the Benencia Island (northwest Iberian Peninsula). Botanica mar., v. 51, n. 6, p. 493-505, 2008.

RIOSMENA-RODRIGUEZ，R.; WOELKERLING，W. J.; FOSTER, M. S. Taxonomic reassessment of rhodolithforming species of Lithophyllum (Corallinales, Rhodophyta) in the Gulf of California, Mexico. Phycologia, v. 38, p. 401-417, 1999.

RIUL, P.; TARGINO, C. H.; FARIAS, J. N.; VISSCHER, P. T.; HORTA, P. A. Decrease in Lithothamnion sp. (Rhodophyta) primary production due to the deposition of a thin sediment layer. J. Mar. Biol. Ass. UK, v. 88, p. 17-19, 2008.

ROBINSON, C.J.; GÓMEZ-AGUIRRE, S.; GÓMEZGUTIÉRREZ J. Pacific sardine behaviour related to tidal current dynamics in Bahía Magdalena, Mexico. J. Fish Biol., v. 71, p. 1-19, 2007.

SCHWEERS, T.; WOLFF, M.; KOCH, V.; SINSELDUARTE, F. Population dynamics of Megapitaria squalida (Bivalvia: Veneridae) at Magdalena Bay, Baja California Sur, Mexico. Rev. Biol. trop., v. 54, p. 10031017, 2006.

SCOFFIN, T. P.; STODDART, D. R.; TUDHOPE, A. W.; WOODROFFE, C. Rhodoliths and coralliths of Muri Lagoon, Rarotonga, Cook Islands. Coral Reefs, v. 4, n. 2, p. 71-80, 1985.

SNEED, E. D.; FOLK, R. L. Pebbles in the lower Colorado River, Texas, a study in particle morphogenesis. J. Geol., v. 66, n. 2, p. 114-150, 1958.

STELLER, D. L.; CÁCERES-MARTÍNEZ, C. Coralline algal rhodoliths enhance larval settlement and early growth of the Pacific calico scallop Argopecten ventricosus. Mar. Ecol. Progr. Ser., v. 396, p. 49-60, 2009.

STELLER, D. L.; FOSTER, M. S. Environmental factors influencing distribution and morphology of rhodoliths in Bahía Concepción, B.C.S., Mexico. J. Exp. Mar. Biol. Ecol., v. 194, p. 201-212, 1995.

STELLER, D. L; RIOSMENA-RODRÍGUEZ, R.; FOSTER, M. S., ROBERTS, C. A. Rhodolith bed diversity in the Gulf of California: The importance of rhodolith structure and consequences of disturbance. Aquat. Conserv.: Mar. Freshw. Ecosyst., v. 13, p. S5-S20, 2003.

STELLER, D. L.; HERNÁNDEZ-AYÓN, J. M.; CABELLOPASINI, A. Effect of temperature on photosynthesis, growth and calcification rates of the free-living coralline alga Lithophyllum margaritae. Cienc. Mar., v. 33, p. 443-448, 2007.

STELLER, D. L.; FOSTER, M. S.; RIOSMENARODRÍGUEZ, R. Living rhodolith bed ecosystems in the Gulf of California, In: JOHNSON, J. M., LEDESMAVÁZQUEZ, J. (Eds.). Atlas of Coastal Ecosystems in the 
Gulf of California: Past and Present. University of Arizona Press, p. 72-82, 2009.

UNDERWOOD, A. J.; KINGSFORD, M. J.; ANDREW, N.

L. Patterns in shallow subtidal marine assemblages along the coast of New South Wales. Aust. Ecol., v. 16, p. $231-49,1991$

(Manuscript received 22 January 2011; revised 30 March 2011; accepted 09 June 2011) 